\title{
Alteration of circulating natural antibodies against VEGFR1-derived peptide antigens in atherosclerosis
}

\section{Peng Wang}

The Second Hospital of Jilin University

\section{Siqi Liu}

The Second Hospital of Jilin University

\section{Zhenqi Wang}

School of Public Health of Jilin University

Huan Zhao

The Second Hospital of Jilin University

\section{Xuan Zhang ( $\nabla$ zhangxuankj@163.com )}

Jilin University Second Hospital https://orcid.org/0000-0003-2503-455X

\section{Research}

Keywords: Atherosclerosis, natural antibody, VEGFR1, ELISA

Posted Date: January 17th, 2020

DOI: https://doi.org/10.21203/rs.2.21125/v1

License: (c) (1) This work is licensed under a Creative Commons Attribution 4.0 International License. Read Full License 


\section{Abstract}

Background Several lines of evidence suggest the protective role of natural antibody in common chronic disease like atherosclerosis and cancer. Vascular endothelial growth factor receptors 1 (VEGFR1) and 2 (VEGFR2) are important regulators of angiogenesis and their involvement in developing atherosclerosis cannot be ruled out.

Purpose The present study was designed to develop an in-house enzyme-linked immunosorbent assay to test if natural IgG for VEGFR1 and regulatory T cell markers CD25 and FOXP3 could be associated with atherosclerosis.

Methods A total of 218 patients with atherosclerosis and 200 healthy controls were recruited; all patients had atherosclerotic carotid plaque and carotid intima-media thickness was analyzed using a diagnostic ultrasound system.

Results Mann-Whitney U test demonstrated that plasma anti-VEGFR1 IgG levels were significantly lower in atherosclerosis patients than control subjects $(Z=-2.46, P=0.014)$ although neither anti-CD25 IgG levels nor anti-FOXP3 IgG levels showed significant changes. Male patients mainly contributed to the decreased antiVEGFR1 lgG levels $(Z=-2.45, P=0.014)$. Spearman correlation analysis failed to show any significant correlation between natural IgG levels and carotid intima-media thickness.

Conclusion Decreased levels of anti-VEGFR1 lgG may be involved in developing atherosclerosis-related conditions.

\section{Introduction}

Atherosclerosis is a chronic inflammatory disorder developed within the wall of large and medium-sized arteries and responsible for several adverse clinical events including acute coronary syndrome and ischemic stroke [1,2]. The disease is characterized by inflammatory infiltrates, subendothelial accumulation of oxidized lipids, angiogenesis and fibrosis. Both innate immunity and adaptive immunity contribute to a proatherogenic inflammatory response that occurs in every step of atherosclerosis development, from the beginning of the fatty streak to plaque rupture [3-6]. The pathogenic event of atherogenesis is a progressive process associated endothelial dysfunction, inflammatory cell adhesion and oxidative stress [7]. Vascular endothelial growth factor (VEGF) receptors 1 (VEGFR1) and 2 (VEGFR2) are important regulators of angiogenesis and their involvement in developing atherosclerosis cannot be ruled out [8]. In function, VEGFs stimulate the angiogenesis via activation of VEGFR2 while VEGFR1 has been thought to down-regulate the function of VEGFR2 $[9,10]$.

Regulatory $\mathrm{T}$ (Treg) cells were characterized as $\mathrm{CD} 4^{+} \mathrm{CD} 25^{+} \mathrm{T}$ cells that could suppress excessive immune response and maintain immune tolerance in periphery [11]. Treg cells can also specifically express fork-head box P3 (FOXP3), a master regulator that is critical for their development and immunosuppressive function and is considered as one of the most reliable molecular markers for Treg 
cells $[12,13]$. Treg cells have been found to suppress atherosclerosis development or progression by down-regulating effector T cells (Teff)-mediated inflammatory response via multiple mechanisms, such as secretion of inhibitory cytokines interleukin (IL)10 (IL-10) and transforming growth factor beta (TGF- $\beta$ ) [1], cell-contact dependent suppression [14] and depletion of the IL-2 [15]. Several studies of experimental atherosclerosis showed that adoptive transfer of Treg cells prevented the development of atherosclerosis [16], while depletion of Treg cells by anti-CD25 antibody boosted the formation of atherosclerotic plaque [17].

Natural antibodies are immunoglobulin generated by innate B cells such as B-1 lymphocytes without any immunization and play an important role in maintaining immune homeostasis in the body [18-20]. The levels of natural antibodies are decreased with advancing age, so that an age-related loss in amount or efficacy of natural antibodies may increase risk of developing several diseases such as atherosclerosis, type-2 diabetes, Alzheimer's disease and malignancy [21]. To date, natural antibodies have found to be involved in several common chronic diseases such as amyloid proteins-related neurodegeneration [22] and cancer [23]. In a recent study, we found that decreased levels of natural antibodies against CD25derived peptide antigens were associated with the development of lung cancer [24].

The present study was designed to determine the levels of natural antibodies against peptide antigens derived from CD25, FOXP3 and VEGFR1 in atherosclerosis and to confirm if these antibodies are associated with development of atherosclerosis.

\section{Materials And Methods}

\section{Subjects}

Plasma samples were collected from 218 patients with atherosclerosis, who were admitted to the Department of Neurology, Second Hospital of Jilin University, Changchun in the period between November 2015 and March 2017. Of these 218 patients aged 61.1 \pm 11.4 years, 127 were male and 91 were female. All patients had atherosclerotic carotid plaque and carotid intima-media thickness (CIMT) was analyzed using a diagnostic ultrasound system (iE Elite, Philips, USA). A total of 200 healthy subjects aged $60.9 \pm 11.7$ years were simultaneously recruited from local communities, 109 of whom were male and 91 were female. Demographic information and clinical characteristics of these participants are given in Table 1. Those participants who had suffered from any type of malignancy and autoimmune disorders such as autoimmune thyroid disease, pernicious anemia, type- 1 diabetes, celiac disease, multiple sclerosis, systemic lupus erythematosus and inflammatory bowel diseases were excluded from this study. All participants were of Chinese Han origin and all signed informed consent to donate their blood samples for this study as approved by the Ethics Committee of Second Hospital of Jilin University in accordance with the ethical guidelines of the Declaration of Helsinki.

Detection of plasma IgG levels 
Seven linear peptide antigens, including three derived from CD25 (CD25a, CD25b and CD25c), two derived from FOXP3 (FOXP3a and FOXP3b) and two derived from VEGFR1 (VEGFR1a and VEGFR1b) were designed based on a computational epitope prediction software (http://www.iedb.org) and synthesized by solid-phase chemistry with a purity of $₫ 95 \%$. The sequence information of these five peptide antigens is shown in Table 2. Enzyme-linked immunosorbent assay (ELISA) was developed in-house for detection of plasma IgG levels for the above three target molecules as described in previous reports [24, 25]. In order to minimize the effect of non-specific binding on the accuracy of experimental data, the specific binding ratio (SBR) was used to represent a relative level of plasma IgG for CD25, FOXP3 and VEGFR1. SBR was calculated as follows:

$\mathrm{SBR}=\left(O D_{\text {sample }}-O D_{N C}\right) /\left(O D_{P C}-O D_{N C}\right)$

Pooled plasma from $₫ 100$ unrelated healthy individuals was used as quality control (QC) sample and tested on every plate. The reproducibility of the in-house ELISA was evaluated by the inter-assay deviation with calculation of the coefficient of variation (CV).

\section{Statistical analysis}

All antibody test data were expressed as means \pm standard deviation (SD). Statistical analysis was performed with the IBM SPSS 22.0 software. Based on Kolmogorov-Smirnov one-sample test for the normality of the distribution of plasma IgG levels, Mann-Whitney $U$ test was used to examine the difference in plasma IgG levels between the patient group and the control group. Spearman correlation analysis was used to examine the relationship between the levels of plasma IgG for CD25, FOXP3 or VEGFR1 and carotid intima-media thickness. A $P$-value of $<0.017$ was considered statistically significant as three target molecules were independently tested in this study.

\section{Results}

The in-house ELISA showed a good reproducibility with a CV value ranging from $7.37 \%$ to $21.15 \%$ (Table 3). As shown in Table 4, plasma IgG levels for VEGFR1b were significantly decreased in patients with atherosclerosis compared with control subjects $(Z=-2.46, P=0.014)$ and male patients appeared to contribute to the decreased anti-VEGFR1b IgG levels $(Z=-2.45, P=0.014)$. Plasma IgG levels for other six peptide antigens failed to show significant differences between the patient group and the control group.

There was no correlation between carotid intima-media thickness and plasma IgG levels for CD25, FOXP3 or VEGFR1 (Table 5).

\section{Discussion}

The present study demonstrated that plasma IgG levels for VEGFR1-derived peptide antigen VEGFR1b were significantly lower in patients with atherosclerosis as compared with healthy controls, especially in male patients (Table 4), suggesting that dysfunction of VEGFR1 is likely to be involved in developing 
atherosclerosis, although we failed to find a significant correlation between anti-VEGFR1b IgG levels and carotid intima-media thickness (Table 5). VEGFR family consists of three transmembrane receptors with tyrosine kinase activity, including VEGFR1, VEGFR2 and VEGFR3 [26]. VEGFR1 and VEGFR2 are highly expressed in vascular endothelial cells while VEGFR3 is mainly localized in lymphatic endothelial cells [27]. Because most VEGFR1 isoforms are soluble, they can block VEGF binding to VEGFR2 and influence the formation of blood vessels. It has been reported that bevacizumab that is anti-VEGF monoclonal antibody for treatment of solid cancer could produce cardiovascular toxicity [28]. Possibly, the imbalance between VEGFR1 and VEGFR2 contributes to the development of atherosclerosis.

Several reports have demonstrated that oxidized low-density lipoprotein (oxLDL), a trigger of atherogenesis, may be involved in inhibiting Treg cells [29]. OxLDL can induce the apoptosis of Treg cells and hamper their immunosuppressive function through down-regulation of FOXP3 expression [30-32]. Recent work has suggested that activated Treg cells suppress the atherosclerosis progression and that FOXP3 genetically controls a transcriptional program that acts protectively in human atherosclerotic plaques [33]. Although our study has failed to show a significant change in circulating IgG for CD25 and FOXP3, there was a trend toward a decrease in anti-FOXP3b IgG levels in patients with atherosclerosis (Table 4). Further investigation is needed to test circulating IgG against a range of peptide antigens derived from FOXP3 protein.

It has long been noted that there is a gender difference in the pathophysiology of atherosclerosis [34, 35]. The gender differences in sex hormones and genetic background may be associated with susceptibility to atherosclerosis in men [36]. The present study found that there was a gender difference in circulating natural antibodies and a significant decrease in anti-VEGFR1b IgG levels was observed only in male patients (Table 4). This finding supports the hypothesis that males are more likely to develop atherosclerosis than females [36].

\section{Conclusion}

Deficiency of plasma anti-VEGFR1 IgG is likely to contribute to the development of atherosclerosis; decreased anti-VEGFR1b IgG levels in the circulation may be a useful biomarker for identification of a subgroup of atherosclerosis-related conditions in which dysfunction of VEGFR1 may be involved.

\section{Abbreviations}

BSA:Bovine serum albumin; Cl:Confident interval; CIMT:Carotid intima-media thickness; CV:Coefficients of variation; ELISA:Enzyme-linked immunosorbent assay; FOXP3:Fork-head box P3; IL-10:Interleukin 10; NC:Negative control; OD:Optical density; oxLDL:Oxidized low-density lipoprotein; PBS:Phosphate buffered saline; PC:Positive control; QC:Quality control; SBR:Specific binding ratio; SD:Standard deviation; TGF- $\beta$ :Transforming growth factor beta; Treg:Regulatory T cells; VEGF:Vascular endothelial growth factor; VEGFR1:VEGF receptors 1; VEGFR2:VEGF receptor 2. 


\section{Declarations}

\section{Ethical approval and consent to participate}

This work was approved by the Ethics Committees of the Second Hospital of Jilin University, Changchun, China, (IRB\#: SHJU2017-099). All procedures performed in studies involving human participants were in accordance with the ethical standards of the institutional and/or national research committee and with the 1964 Helsinki declaration and its later amendments or comparable ethical standards.

\section{Consent for publication}

All patients or their surrogates provided informed consent for this study.

\section{Availability of data and materials}

The datasets used and/or analysed during the current study are available from the corresponding author on reasonable request.

\section{Competing Interests}

The authors declare that they have no conflict of interests.

\section{Funding}

This study was supported by Hailanshen Biomedical Technology Ltd, Shenzhen, China.

\section{Author's contributions}

PW and SL carried out laboratory work, data analysis and drafting the manuscript; ZW and HZ were responsible for identification of patients and healthy controls, and collection of samples and clinical information; XZ conceived of this study, supervised laboratory work and data analysis, and corrected the manuscript.

\section{Acknowledgements}

We thank the patients and healthy volunteers for their support and participation.

\section{References}

[1] Ou HX, Guo BB, Liu Q, Li YK, Yang Z, Feng WJ, Mo ZC. Regulatory T cells as a new therapeutic target for atherosclerosis. Acta Pharmacol Sin. 2018; 39:1249-58.

[2] Taleb S. Inflammation in atherosclerosis. Arch Cardiovasc Dis. 2016; 109:708-15. 
[3] Hansson GK, Hermansson A. The immune system in atherosclerosis. Nat Immunol. 2011; 12:20412.

[4] Butcher MJ, Filipowicz AR, Waseem TC, McGary CM, Crow KJ, Magilnick N, Boldin M, Lundberg PS and Galkina EV. Atherosclerosis-Driven Treg Plasticity Results in Formation of a Dysfunctional Subset of Plastic IFNgamma+ Th1/Tregs. Circ Res 2016; 119: 1190-1203.

[5] Hansson GK and Libby P. The immune response in atherosclerosis: a double-edged sword. Nat Rev Immunol 2006; 6: 508-519.

[6] Andersson J, Libby P, Hansson GK. Adaptive immunity and atherosclerosis. Clin Immunol. 2010; 134:33-46.

[7] Camaré $C$, Pucelle $M$, Nègre-Salvayre A, Salvayre R. Angiogenesis in the atherosclerotic plaque. Redox Biol. 2017; 12:18-34.

[8] Imoukhuede PI, Dokun AO, Annex BH, Popel AS. Endothelial cell-by-cell profiling reveals the temporal dynamics of VEGFR1 and VEGFR2 membrane localization after murine hindlimb ischemia. Am J Physiol Heart Circ Physiol. 2013; 304: H1085-93.

[9] Autiero M, Luttun A, Tjwa M, Carmeliet P. Placental growth factor and its receptor, vascular endothelial growth factor receptor-1: novel targets for stimulation of ischemic tissue revascularization and inhibition of angiogenic and inflammatory disorders. J Thromb Haemost. 2003; 1:1356-70.

[10] Wu FT, Stefanini MO, Mac Gabhann F, Kontos CD, Annex BH, Popel AS. A systems biology perspective on sVEGFR1: its biological function, pathogenic role and therapeutic use. J Cell Mol Med. $2010 ; 14: 528-52$.

[11] Sakaguchi S, Yamaguchi T, Nomura T, Ono M. Regulatory T cells and immune tolerance. Cell 2008; 133:775-87.

[12] Sasaki N, Yamashita T, Takeda M, Hirata K. Regulatory T cells in atherogenesis. J Atheroscler Thromb. 2012; 19:503-15.

[13] Hori S, Nomura T, Sakaguchi S. Control of regulatory T cell development by the transcription factor Foxp3. Science 2003; 299:1057-61.

[14] Pastrana JL, Sha X, Virtue A, Mai J, Cueto R, Lee IA, Wang H, Yang XF. Regulatory T cells and Atherosclerosis. J Clin Exp Cardiolog. 2012; 2012: 2.

[15] Pandiyan P, Zheng L, Ishihara S, Reed J, Lenardo MJ. CD4+CD25+Foxp3+ regulatory T cells induce cytokine deprivation-mediated apoptosis of effector CD4+ T cells. Nat Immunol. 2007; 8:1353-62. 
[16] Mallat Z, Gojova A, Brun V, Esposito B, Fournier N, Cottrez F, Tedgui A, Groux H. Induction of a regulatory $T$ cell type 1 response reduces the development of atherosclerosis in apolipoprotein $\mathrm{E}$ knockout mice. Circulation 2003; 108:1232-7.

[17] Ait-Oufella H, Salomon BL, Potteaux S, Robertson AK, Gourdy P, Zoll J, Merval R, Esposito B, Cohen JL, Fisson S, Flavell RA, Hansson GK, Klatzmann D, Tedgui A, Mallat Z. Natural regulatory T cells control the development of atherosclerosis in mice. Nat Med. 2006; 12:178-80.

[18] Coutinho A, Kazatchkine MD, Avrameas S. Natural autoantibodies. Curr Opin Immunol. 1995; 7:812-8.

[19] Silosi I, Silosi CA, Boldeanu MV, Cojocaru M, Biciusca V, Avramescu CS, Cojocaru IM, Bogdan M, FolcuTi RM. The role of autoantibodies in health and disease. Rom J Morphol Embryol. 2016; 57:633-8.

[20] Holodick NE, Rodríguez-Zhurbenko N, Hernández AM. Defining Natural Antibodies. Front Immunol. $2017 ; 8: 872$.

[21] Rothstein TL. Natural Antibodies as Rheostats for Susceptibility to Chronic Diseases in the Aged. Front Immunol. 2016; 7:127.

[22] Britschgi M, Olin CE, Johns HT, Takeda-Uchimura Y, LeMieux MC, Rufibach K, Rajadas J, Zhang H, Tomooka B, Robinson WH, Clark CM, Fagan AM, Galasko DR, Holtzman DM, Jutel M, Kaye JA, Lemere CA, Leszek J, Li G, Peskind ER, Quinn JF, Yesavage JA, Ghiso JA, Wyss-Coray T. Neuroprotective natural antibodies to assemblies of amyloidogenic peptides decrease with normal aging and advancing Alzheimer's disease. Proc Natl Acad Sci USA. 2009; 106:12145-50.

[23] Hernandez AM, Toledo D, Martinez D, Grinan T, Brito V, Macias A, Alfonso S, Rondon T, Suarez E, Vazquez AM, Perez R. Characterization of the antibody response against NeuGcGM3 ganglioside elicited in non-small cell lung cancer patients immunized with an anti-idiotype antibody. J Immunol. 2008; 181:6625-34.

[24] Zhao H, Zhang X, Han Z, Xie W, Yang W, Wei J. Alteration of circulating natural autoantibodies to CD25-derived peptide antigens and FOXP3 in non-small cell lung cancer. Sci Rep. 2018; 8:9847.

[25] Hallford P, St Clair D, Halley L, Mustard C, Wei J. A study of type-1 diabetes associated autoantibodies in schizophrenia. Schizophr Res. 2016; 176:186-90.

[26] Roskoski R Jr. Vascular endothelial growth factor (VEGF) and VEGF receptor inhibitors in the treatment of renal cell carcinomas. Pharmacol Res. 2017; 120:116-32.

[27] Hoeben A, Landuyt B, Highley MS, Wildiers H, Van Oosterom AT, De Bruijn EA. Vascular endothelial growth factor and angiogenesis. Pharmacol Rev. 2004; 56: 549-80. 
[28] Economopoulou P, Kotsakis A, Kapiris I, Kentepozidis N. Cancer therapy and cardiovascular risk: focus on bevacizumab. Cancer Manag Res 2015; 7:133-43.

[29] Zhang WC, Wang J, Shu YW, Tang TT, Zhu ZF, Xia N, Nie SF, Liu J, Zhou SF, Li JJ, Xiao H, Yuan J, Liao MY, Cheng LX, Liao YH, Cheng X. Impaired thymic export and increased apoptosis account for regulatory $\mathrm{T}$ cell defects in patients with non-ST segment elevation acute coronary syndrome. J Biol Chem. 2012; 287: 34157-66.

[30] Mor A, Planer D, Luboshits G, Afek A, Metzger S, Chajek-Shaul T, Keren G and George J. Role of naturally occurring $\mathrm{CD} 4+\mathrm{CD} 25+$ regulatory $\mathrm{T}$ cells in experimental atherosclerosis. Arterioscler Thromb Vasc Biol 2007; 27: 893-900.

[31] Mor A, Luboshits G, Planer D, Keren G, George J. Altered status of CD4(+)CD25(+) regulatory T cells in patients with acute coronary syndromes. Eur Heart J 2006; 27: 2530-2537.

[32] Jia L, Zhu L, Wang JZ, Wang XJ, Chen JZ, Song L, Wu YJ, Sun K, Yuan ZY, Hui R. Methylation of FOXP3 in regulatory $T$ cells is related to the severity of coronary artery disease. Atherosclerosis 2013; 228 : 346-352.

[33] Joly AL, Seitz C, Liu S, Kuznetsov NV, Gertow K, Westerberg LS, Paulsson-Berne G, Hansson GK, Andersson J. Alternative splicing of FOXP3 controls regulatory T cell effector functions and is Associated with human atherosclerotic plaque stability. Circ Res 2018 11; 122: 1385-1394.

[34] Mendelsohn ME, Karas RH. Molecular and cellular basis of cardiovascular gender differences. Science $2005 ;$ 308:1583-7.

[35] Mathur P, Ostadal B, Romeo F, Mehta JL. Gender-Related Differences in Atherosclerosis. Cardiovasc Drugs Ther. 2015; 29:319-27.

[36] Ng MK, Quinn CM, McCrohon JA, Nakhla S, Jessup W, Handelsman DJ, Celermajer DS, Death AK. Androgens up-regulate atherosclerosis-related genes in macrophages from males but not females: molecular insights into gender differences in atherosclerosis. J Am Coll Cardiol. 2003; 42:1306-13.

\section{Tables}

Table 1. Demographic and clinical characteristics of patients with atherosclerosis and control subjects 


\begin{tabular}{lll}
\hline Characteristics & Patients & Controls \\
\hline Gender & $127(58.3 \%)$ & $109(54.5 \%)$ \\
$\quad$ Male & $91(41.7 \%)$ & $91(45.5 \%)$ \\
Female & $61.2 \pm 11.4$ & $60.9 \pm 11.7$ \\
Sge (years) & & \\
Smoking history & $106(48.4 \%)$ & $98(49 \%)$ \\
Non-smoker & $113(51.6 \%)$ & $102(51 \%)$ \\
Site of plaques & & \\
Carotid artery & $6(2.7)$ & -- \\
Carotid bifurcation & $51(23.3)$ & -- \\
Internal carotid artery & $39(17.8)$ & -- \\
Internal carotid bifurcation & $2(0.9)$ & -- \\
Common carotid artery & $100(45.7)$ & -- \\
Subclavian artery & $20(9.1)$ & -- \\
\hline
\end{tabular}

Table 2. The sequence information for peptide antigens derived from three target molecules

\begin{tabular}{llcc} 
Antigen & \multicolumn{1}{c}{ Sequence $(\mathrm{N} \rightarrow \mathrm{C})$} & NCBI Accession & Position (aa) \\
\hline CD25a & kpghcrepppweneateriyhfvvgqmvy & NP_000408 & $99-126$ \\
CD25b & iyhfvvgqmvyyqcvqgyralhrgpaesve & NP_000408 & $116-144$ \\
CD25c & khtsqfpgeekpqaspegrpesetsch & NP_000408 & $167-187$ \\
FOXP3a & dmfaffrnhpatwknairhnlslhkcd & NP_001107849 & $335-359$ \\
FOXP3b & Kctfpnpsaprkdstlsavpqssyh & NP_001107849 & $134-156$ \\
VEGFR1a & degvyhckatnqkgsvessayltvqgtsdk & NP_002010 & $725-754$ \\
VEGFR1b & cqitwfknnhkiqqepgiilg pgsstd & NP_002010 & $691-715$ \\
\hline
\end{tabular}

Table 3. Inter-assay deviation of the in-house ELISA for plasma IgG antibodies 


\begin{tabular}{lcc}
\hline Antibody & No of plates & Coefficient of variation (\%) \\
\hline CD25a & 20 & 19.1 \\
CD25b & 20 & 12.2 \\
CD25c & 20 & 21.2 \\
FOXP3a & 20 & 12.0 \\
FOXP3b & 20 & 10.8 \\
VEGFR1a & 20 & 7.4 \\
VEGFR1b & 20 & 11.9 \\
\hline
\end{tabular}

Table 4. The levels of plasma IgG against CD25, FOXP3 and VEGFR1 in patients with atherosclerosis and control subjects 


\begin{tabular}{|c|c|c|c|c|c|}
\hline $\operatorname{Ig} G$ & Group & Patient (n) & Control (n) & $\mathrm{Z}^{\mathrm{a}}$ & $P^{\mathrm{b}}$ \\
\hline \multirow[t]{3}{*}{ CD25a } & Male & $0.73 \pm 0.20(127)$ & $0.72 \pm 0.19(109)$ & 0.40 & 0.686 \\
\hline & Female & $0.75 \pm 0.21$ & $0.70 \pm 0.21(91)$ & 1.41 & 0.158 \\
\hline & Both & $0.73 \pm 0.20(218)$ & $0.71 \pm 0.20(200)$ & 1.20 & 0.231 \\
\hline \multirow[t]{3}{*}{$\mathrm{CD} 25 \mathrm{~b}$} & Male & $0.81 \pm 0.21(127)$ & $0.80 \pm 0.23(109)$ & 0.43 & 0.669 \\
\hline & Female & $0.84 \pm 0.19(91)$ & $0.82 \pm 0.19(91)$ & 0.99 & 0.323 \\
\hline & Both & $0.82 \pm 0.20(218)$ & $0.81 \pm 0.21(200)$ & 0.92 & 0.359 \\
\hline \multirow[t]{3}{*}{ CD25c } & Male & $1.32 \pm 0.43(127)$ & $1.31 \pm 0.51(109)$ & 0.49 & 0.622 \\
\hline & Female & $1.37 \pm 0.46(91)$ & $1.29 \pm 0.48(91)$ & 1.26 & 0.208 \\
\hline & Both & $1.34 \pm 0.44(218)$ & $1.30 \pm 0.49(200)$ & 1.22 & 0.222 \\
\hline \multirow[t]{3}{*}{ FOXP3a } & Male & $0.93 \pm 0.28(127)$ & $0.92 \pm 0.24(109)$ & -0.15 & 0.878 \\
\hline & Female & $0.97 \pm 0.27(91)$ & $0.92 \pm 0.20(91)$ & 1.09 & 0.274 \\
\hline & Both & $0.94 \pm 0.27(218)$ & $0.93 \pm 0.23(200)$ & -0.53 & 0.594 \\
\hline \multirow[t]{3}{*}{ FOXP3b } & Male & $0.85 \pm 0.25(127)$ & $0.92 \pm 0.25(109)$ & -2.17 & 0.03 \\
\hline & Female & $0.91 \pm 0.25(91)$ & $0.93 \pm 0.21(91)$ & -0.74 & 0457 \\
\hline & Both & $0.87 \pm 0.25(218)$ & $0.92 \pm 0.23(200)$ & -2.224 & 0.025 \\
\hline \multirow[t]{3}{*}{ VEGFR1a } & Male & $1.56 \pm 0.45(127)$ & $1.65 \pm 0.42(109)$ & -1.83 & 0.067 \\
\hline & Female & $1.67 \pm 0.57(91)$ & $1.67 \pm 0.47(91)$ & -0.53 & 0.595 \\
\hline & Both & $1.60 \pm 0.50(218)$ & $1.66 \pm 0.44(200)$ & -1.82 & 0.069 \\
\hline \multirow[t]{3}{*}{ VEGFR1b } & Male & $1.44 \pm 0.39(127)$ & $156 \pm 0.38(109)$ & -2.45 & 0.014 \\
\hline & Female & $1.59 \pm 0.52(91)$ & $1.60 \pm 0.41(91)$ & -0.81 & 0.416 \\
\hline & Both & $1.50 \pm 0.45(218)$ & $1.58 \pm 0.39(200)$ & -2.46 & 0.014 \\
\hline
\end{tabular}

Plasma IgG levels are expressed as mean \pm SD in SBR. ${ }^{\text {a }}$ Mann-Whiteney $U$ test; ${ }^{\text {b }} P<0.017$ was considered statistically significant.

Table 5. Spearman correlation analysis of the relationship between carotid intima-media thickness and plasma IgG levels for CD25, FOXP3 and VEGFR1 


\begin{tabular}{lccc}
\hline Antibody & df & Coefficients of correlation (r) & $P$ \\
\hline CD25a & 216 & -0.011 & 0.870 \\
CD25b & 216 & -0.057 & 0.405 \\
CD25c & 216 & -0.026 & 0.698 \\
FOXP3a & 216 & 0.015 & 0.829 \\
FOXP3b & 216 & -0.020 & 0.765 \\
VEGFR1a & 216 & 0.018 & 0.788 \\
VEGFR1b & 216 & -0.020 & 0.765 \\
\hline
\end{tabular}

